\title{
Erratum
}

\section{Demarcation of ilarviruses based on the phylogeny of RNA2-encoded RdRp and a generic ramped annealing RT-PCR}

\author{
V. I. Maliogka, C. I. Dovas, N. I. Katis \\ [Arch Virol (2007) 152: 1687-1698, DOI 10.1007/s00705-007-0995-0]
}

The original version of this paper unfortunately contained a mistake on page 1690, second column, first paragraph, primer concentrations were given incorrectly.

The correct sentence (starting in first column last paragraph) is:

“The first RT-PCR was carried out with $1 \mu \mathrm{l}$ of RNA in a final volume of $25 \mu \mathrm{l}$ containing $10 \mathrm{mM}$ Tris$\mathrm{HCl}$ [pH 8.8], $50 \mathrm{mM} \mathrm{KCl}, 1.5 \mathrm{mM} \mathrm{MgCl}_{2}, 0.1 \%$ Triton X-100, $0.25 \mathrm{mM}$ of each deoxyribonucleoside triphosphate (dNTP), 5.0 mM DTT, 5\% dimethyl sulphoxide (DMSO), 12 units of ribonuclease inhibitor (HT Biotechnology, England), 0.7 units of Superscript ${ }^{\mathrm{TM}}$ II Rnase H-Reverse Transcriptase (Invitrogen, The Netherlands), 0.7 units of Avian Myeloblastosis Virus Reverse Transcriptase (Finnzymes, Finland), 1.5 units of Taq Platinum DNA Polymerase (Invitrogen, The Netherlands) and $1 \boldsymbol{\mu M}$ each of the primers "Ilapol up2" and "Ilapol do4". Nested PCR reaction $(20 \mu \mathrm{l})$ was performed using $1 \mu \mathrm{l}$ of the first RT-PCR product. The reaction mixture contained $10 \mathrm{mM}$ Tris- $\mathrm{HCl}[\mathrm{pH} 8.8], 50 \mathrm{mM} \mathrm{KCl}, 1.5 \mathrm{mM} \mathrm{MgCl} 2,0.1 \%$ Triton X-100, $0.2 \mathrm{mM}$ of each dNTP, 1 unit of Taq Platinum DNA Polymerase and $\mathbf{1} \boldsymbol{\mu M}$ each of "Ilapolnest up3" and "Ilapolnest d5" primers."

Authors apologize for the error.

\footnotetext{
Verleger: Springer-Verlag GmbH, Sachsenplatz 4-6, 1201 Wien, Austria - Herausgeber: Dr. M. H. V. Van Regenmortel, École Supérieure de Biotechnologie de Strasbourg (ESBS) Parc d'Innovation, Boulevard Sébastian Brandt, 67400 Illkirch, France. - Redaktion: Sachsenplatz 4-6, 1201 Wien, Austria Hersteller: Satz und Umbruch: Thomson Press (India) Ltd., Chennai; Offsetdruck: Krips bv, Kaapweg 6, 7944 HV Meppel, The Netherlands - Verlagsort: Wien - Herstellungsort: Meppel - Printed in The Netherlands.
} 